Annals of International Medical and Dental Research

E-ISSN: 2395-2822 | P-ISSN: 2395-2814

Vol-8, Issue-2 | March-April 2022

DOI: 10.53339/aimdr.2022.8.2.27

Page no- 209-218 | Section- Research Article (Cardiac Surgery)

\title{
Acute Phase Response and its Effect on Short Term Outcome of Bangladeshi patients after On-Pump Cardiac Surgery
}

\author{
Omar Sadeque Khan ${ }^{1 *}$, Rezwanul Hoque ${ }^{2}$, Md. Mostafizur Rahman ${ }^{3}$, Jesmeen Morshed ${ }^{4}$, Heemel \\ Saha $^{5}$, Nasif Imtiaz
}

1Assistant Professor, Department of Cardiac Surgery, Bangabandhu Sheikh Mujib Medical University, Dhaka, Bangladesh.

Email: omar_m32@hotmail.com

Orcid ID: 0000-0003387-7116

2Professor, Department of Cardiac Surgery, Bangabandhu Sheikh Mujib Medical University, Dhaka, Bangladesh. O

rcid ID: 0000-0003-3261-5782

3Professor and Chairman, Department of Cardiac Surgery, Bangladesh Sheikh Mujib Medical University, Dhaka, Bangladesh.

Orcid ID: 0000-0002-4715-3173

4Medical Officer, Department of Paediatrics, Bangladesh Sheikh Mujib Medical University, Dhaka, Bangladesh.

Email: jesm32@gmail.com,

Orcid ID: 0000-00025175-0376

${ }^{5}$ Assistant Professor, Department of Thoracic Surgery, Bangabandhu Sheikh Mujib Medical University, Dhaka, Bangladesh.

Email: heemelsaha@gmail.com,

Orcid ID: 0000-0002-7020-5840

6Medical Officer, Department of Anaesthesia, Analgesia and Intensive Care Medicine, Bangabandhu Sheikh Mujib, Medical University.Dhaka, Bangladesh.

Email: imtiaznasif@yahoo.com,

Orcid ID: 0000-0001-8868-4344

*Corresponding author

Received: 18 November 2021

Revised: 14 January 2022

Accepted: 28 January 2022

Published: 18 February 2022

\begin{abstract}
Background: Throughout any surgical procedure, the immune system is generally activated as a physiological response to the surgical trauma. Cardiopulmonary bypass can trigger the inflammatory response in three ways: direct contact activation of the immune system due to exposer of blood to foreign surfaces, ischaemia-reperfusion injury to vital organs as a result of aortic cross clamping, and splanchnic hypoperfusion. Objective: The aim of the study was to observe the acute phase response variables in Bangladeshi patients and to assess the acute phase response and morbidity of the patients after prolonged bypass surgery. Methods: This cross sectional study was conducted in the Department of Cardiac Surgery, BSMMU from January 2009 to December 2010. Fifty patients were selected for the study and were divided into 2 groups on the basis of cardiopulmonary bypass time. Group I was cardiopulmonary bypass time less than 90 minutes and Group II was more than 90 minutes. Data were stored and analyzed with standard computer software (SPSS-15). P $<0.05$ was considered statistically significant. Results: The mean duration of cardiopulmonary bypass $(\mathrm{CPB})$ time $(55.76 \pm 10.8$ in group I, $131 \pm 31.35$ in group II; $\mathrm{P}<0.001)$ and Aortic cross clamp time (28.48 \pm 8.31 in group I, 83.48 \pm 30.99 in group II; $\mathrm{P}<0.001$ ) was higher in group II than group I. Analysis of outcome variables showed that mean postoperative ventilation time was $6.24 \pm 1.20$ in group I and $9.16 \pm 2.33$ in group II. There was significant difference in the ventilation time between two groups $(\mathrm{P}<0.001)$. This study showed that there is a definite relationship of wound infection with the prolonged cardiopulmonary bypass time $(\mathrm{P}<0.001)$ and also persistently rising CRP increases the chance of wound infection. Conclusions: We may conclude that prolonged cardiopulmonary bypass time is associated with increased acute phase response and morbidity of Bangladeshi patients.
\end{abstract}

Keywords:- Acute phase response, On-Pump Cardiac Surgery, Cardiopulmonary bypass.

\section{INTRODUCTION}

A general activation of the immune system is observed during any operative procedure as a physiological response to the surgical trauma. At that time there is an augmented hepatic synthesis of certain proteins and an increase in their plasma concentration. This is termed the 
Annals of International Medical and Dental Research E-ISSN: 2395-2822 | P-ISSN: 2395-2814

Vol-8, Issue-2 | March-April 2022

DOI: 10.53339/aimdr.2022.8.2.27

Page no- 209-218 | Section- Research Article (Cardiac Surgery)

acute-phase response. The most significant increase is in C-reactive protein and serum amyloid A protein. Also elevated but to a lesser degree are haptoglobin, complement components, caeruloplasmin and fibrinogen. The albumin level is decreased, and the net result is a change that is reflected in an elevated ESR1. Cardiopulmonary bypass may directly activate the inflammatory response by three distinct mechanisms: direct contact activation of the immune system following exposure of blood to the foreign surfaces, ischaemia-reperfusion injury to vital organs as a result of aortic cross clamping and splanhnic hypoperfusion can result in increased permeability of the gut mucosal barrier and consequently endotoxaemia.11] The damaging effects of cardiopulmonary bypass (CPB) and the subsequent inflammatory response are the result of the extreme conditions encountered during extracorporeal support, including (1) cell activation on contact with the foreign surfaces of the bypass circuit, (2) mechanical shear stress, (3) tissue ischaemia and reperfusion, (4) hypotension, (5) nonpulsatile perfusion, (6) haemodilution with relative anaemia, (7) blood product administration, (8) heparin and protamine administration, and (9) hypothermia.[2] Complement activation occurs through both the alternative (stimulated by foreign surface contact, endotoxin and kallikrein) and classical (protamine) pathways. The exposure of blood to extracorporeal circuits activates the alternate pathway, leading to the formation of $\mathrm{C} 3 \mathrm{a}$ and $\mathrm{C} 5 \mathrm{a}$, whereas reversal of heparin with protamine activates the classical pathway with an associated rise in $\mathrm{C} 4 \mathrm{a}$ levels and further rise in C3a levels.[2,3] Polymorphonuclear leukocyte (neutrophil) activation can occur following complement activation by immunologic (antibody mediated: IgM, IgG-antigen activation) or non-immunologic (heparinprotamine, endotoxin) pathways. [4] C-reactive protein is a typical marker of acute inflammation and bacterial infection. CRP is released from the liver and is involved in the acute inflammatory process. [5] Cytokines once initiated, the systemic inflammatory response will be maintained by several factors, including cytokine production. Cytokines (Tumour necrosis factor [TNF], interleukins [IL], interferons [IFN] and colony-stimulating factors) are small proteins generated in tissues under a variety of circumstances. [6] They serve a multiplicity of physiological functions, chiefly acting as intercellular messengers in response to cellular activation. If the stimulus for cytokine production is sustained or of sufficient magnitude, cytokines may become active systemically where they have potential for wide spread pathophysiological effects on the heart, lungs, liver, coagulation system and central nervous system. [7] The cytokines often associated with release during and after cardio-pulmonary bypass include TNF-a, IL$1 \beta$, IL-2, IL-6, IL-8 and IL-10 6. Complications of CPB include coagulation disorders (bleeding diathesis, hyperfibrinolysis) from platelet defects and plasmin activation, as well as pulmonary dysfunction from neutrophil sequestration and degranulation. Diverse injuries are a consequence of multiple inflammatory mediators (complement, kinins, kallikrein, cytokines). Both plasmin and kallikrein amplify the inflammatory response by activating components of the contact activation system. $[7,8]$ Complication of bleeding following open heart surgery is observed in patients with prothrombin time abnormality. 
Annals of International Medical and Dental Research

E-ISSN: 2395-2822 | P-ISSN: 2395-2814

Vol-8, Issue-2 | March-April 2022

DOI: 10.53339/aimdr.2022.8.2.27

Page no- 209-218 | Section- Research Article (Cardiac Surgery)

An elevated international normalized ratio (INR) does not mean that the patient will have more than normal tissue oozing. All those with an INR < 2.0 can undergo an open heart procedure without the problem of increased bleeding. However those with INR more than 2.0 but less than 2.5 should be individualized.[9] For patients after cardiopulmonary bypass surgery, a recent publication demonstrated that an activated partial thromboplastin time biphasic waveform (BPW) analysis was able to discriminate between sepsis and nonseptic systemic inflammatory response syndrome (SIRS) with a sensitivity of $100 \%$ and a specificity of $93 \%$.110] The early and timely differentiation between systemic inflammatory response syndrome (SIRS) and sepsis remains difficult. If an infectious focus becomes clinically evident, it will usually be too late to prevent the beginning of the septic vicious circle (for example, by initiating specific therapies such as antibiotics or surgical interventions). $[10,11]$

Cardiopulmonary bypass itself has timerelated influence on the human body. It causes a systemic inflammatory response through complement activation and damaging platelets, which is more severe as cardiopulmonary bypass time is longer. Bypass-time up to 90 minutes is the reference category.[11,12]

\section{Objectives}

The aim of the study was to observe the acute phase response and its effect (atrial fibrillation, systemic inflammatory response syndrome) on outcome (wound infection, neurocognitive deficit, pneumonia) of on-pump cardiac surgical patients.

\section{Specific objectives}

To observe the acute phase response (eg. increase $\mathrm{C}$-reactive protein, complement $\mathrm{C} 3$ and $\mathrm{C} 4$, neutrophil count, total count of WBC, APTT and INR) occurred in Bangladeshi people after on-pump cardiac surgery.

To observed and compare the short term outcome of on-pump patients with cardiopulmonary bypass time more than 90 minutes and less than 90 minutes.

\section{METHODS}

This study was conducted in the Department of Cardiac Surgery, BSMMU from January 2009 to December 2010. Fifty patients were selected for the study and were divided into 2 groups on the basis of cardiopulmonary bypass time. Study design was Observational study (Cross-Sectional Study). Sampling technique was purposive sampling. Fifty patients were selected for the study and were divided into two groups on the basis of cardiopulmonary bypass time. Group I was cardiopulmonary bypass time less than 90 minutes and Group II was more than 90 minutes. Follow up was taken for upto 10th postoperative day. Patient's data was recorded in a pre-determined data sheet. After taking informed written consent blood samples were collected. With all aseptic precaution $10 \mathrm{ml}$ blood samples were collected in a plain test for the study of total count of WBC, Neutrophil count, C-reactive protein, C3 and C4, APTT, International Normalized Ratio (INR) of Prothrombin time on pre-operatively, 1st postoperatively and 5th postoperative day. Creactive protein was measured by Immunonephelometric system (Cardio phase* 
Annals of International Medical and Dental Research

E-ISSN: 2395-2822 | P-ISSN: 2395-2814

Vol-8, Issue-2 | March-April 2022

DOI: 10.53339/aimdr.2022.8.2.27

Page no- 209-218 | Section- Research Article (Cardiac Surgery)

hs CRP reagent code no. OQIY, Dade Behring, USA). C3c/ C4 by Immunonephelometric system ( $\mathrm{N}$ antiserum to human $\mathrm{C} 3 \mathrm{c}$, code no. OSAP, $\mathrm{N}$ antiserum to human $\mathrm{C} 4$, code no. OSAO, Dade Behring, USA). Activated Partial Thromboplastin Time (APTT) and Prothrombin time (PT) were measured by Automated CA50 coagulometer (Siemens). Terumo Advanced Perfusion System 1 , HeartLung Machine used for Cardiopulmonary Bypass and standard dose of heparin given before going to bypass. Also standard dose of protamine given during withdrawal from bypass. Patient's data were recorded in a predesigned data sheet and analyzed by SPSS 15. Student's t-test and chi-square $(x 2)$ test were done to compare between two groups and one way ANOVA was done to analyze the intragroup comparison of variables. This study has no potential risk to the patients and no experimental drug was used in this study. Before starting the study ethical clearance was taken from the central ethical committee of BSMMU. Informed written consent was taken, all the procedures and benefits of this study was clearly explained to the patients. With all the aseptic precaution, blood collection done from the patient and it was ensured to them that there is no potential risk of this study.

\section{RESULTS}

In group- I, sixty eight (68\%) percent of the patients were in the range of 20-40 years. Twelve percent $(12 \%)$ patients were in the range of less than 20 years; twenty percent $(20 \%)$ patients are above 40 years. In Group- II, Seventy six percent $(76 \%)$ patients were in the range of 20-40 years, eight percent (8\%) patients were less than 20 years and sixteen percent $(16 \%)$ patients were above 40 years.
The patients in Group- II, had higher mean age $32.60 \pm 14.85$ years, compared to Group- I $27.40 \pm 10.64$ years. The difference between the two groups were statistically not significant $(\mathrm{P}$ $=0.162$ ) [Table 1]. [Figure 1] showed the sex distribution of the patients. Out of 50 patients, female was predominant $72 \%$ in Group I, $60 \%$ in Group II. $28 \%$ of the patients in Group I and $40 \%$ in Group II were male. The two groups difference were not statistically significant ( $\mathrm{p}=$ 0.37). [Figure 2] I showed the types of operations that were done in two groups. The mean duration of cardiopulmonary bypass (CPB) time (55.76 \pm 10.8 in group I, 131 \pm 31.35 in group II; $\mathrm{P}<0.001$ ) and Aortic cross clamp time $(28.48 \pm 8.31$ in group I, $83.48 \pm 30.99$ in group II; $\mathrm{P}<0.001)$ was higher in group II than group I [Table 2]. [Table 3] showed in each group, total count of WBC was significantly increased on 1st POD $(\mathrm{P}<0.001)$ and on 5th POD it decreased significantly $(\mathrm{P}<0.001)$. But the difference between two groups in preoperative, $1^{\text {st }}$ postoperative day and 5 th postoperative day were not significant $(\mathrm{P}=$ $0.842, \mathrm{P}=0.545$ and $\mathrm{P}=0.057$ respectively). Analysis of outcome variables showed that mean postoperative ventilation time was $6.24 \pm 1.20$ in group I and $9.16 \pm 2.33$ in group II. There was significant difference in the ventilation time between two groups $(\mathrm{P}<0.001)$ [Table 4]. Again 5(20\%) of the patients in group I developed Atrial fibrillation (AF) in the postoperative period, whereas $12(48 \%)$ of the patients in group II developed atrial fibrillation in postoperative period. The difference between both groups was statistically significant $(\mathrm{P}<0.05)$. Mean length of ICU stay was $5.04 \pm 0.20$ days in group I and $5.76 \pm 1.45$ in group II. The difference was significant $(\mathrm{P}<0.02)$. None of the patients developed 
Annals of International Medical and Dental Research E-ISSN: 2395-2822 | P-ISSN: 2395-2814

Vol-8, Issue-2 | March-April 2022

DOI: 10.53339/aimdr.2022.8.2.27

Page no- 209-218 | Section- Research Article (Cardiac Surgery)

severe systemic inflammatory response syndrome or acute renal failure or severe arrhythmia endangering the life. Only local wound infection occurred in $2(8 \%)$ in group I and $4(16 \%)$ in group II. The difference was significant $(\mathrm{P}<0.001)$. This study showed that there was a definite relationship of wound infection with the prolonged cardiopulmonary bypass time $(\mathrm{P}<0.001)$ and also persistently rising CRP increases the chance of wound infection [Table 5].

Table 1: Age distribution of the study $(n=50)$ groups.

\begin{tabular}{|l|l|l|l|}
\hline Age (years) & Group I (n=25) & Group II (n=25) & P value \\
\hline$<20$ & $3(12 \%)$ & $2(8 \%)$ & 0.162 NS \\
\cline { 1 - 2 } $20-40$ & $17(68 \%)$ & $19(76 \%)$ & \\
\cline { 1 - 2 } & $5(20 \%)$ & $4(16 \%)$ & \\
\cline { 1 - 2 } Mean SD & $27.40 \pm 10.64$ & $32.60 \pm 14.85$ & \\
\hline
\end{tabular}

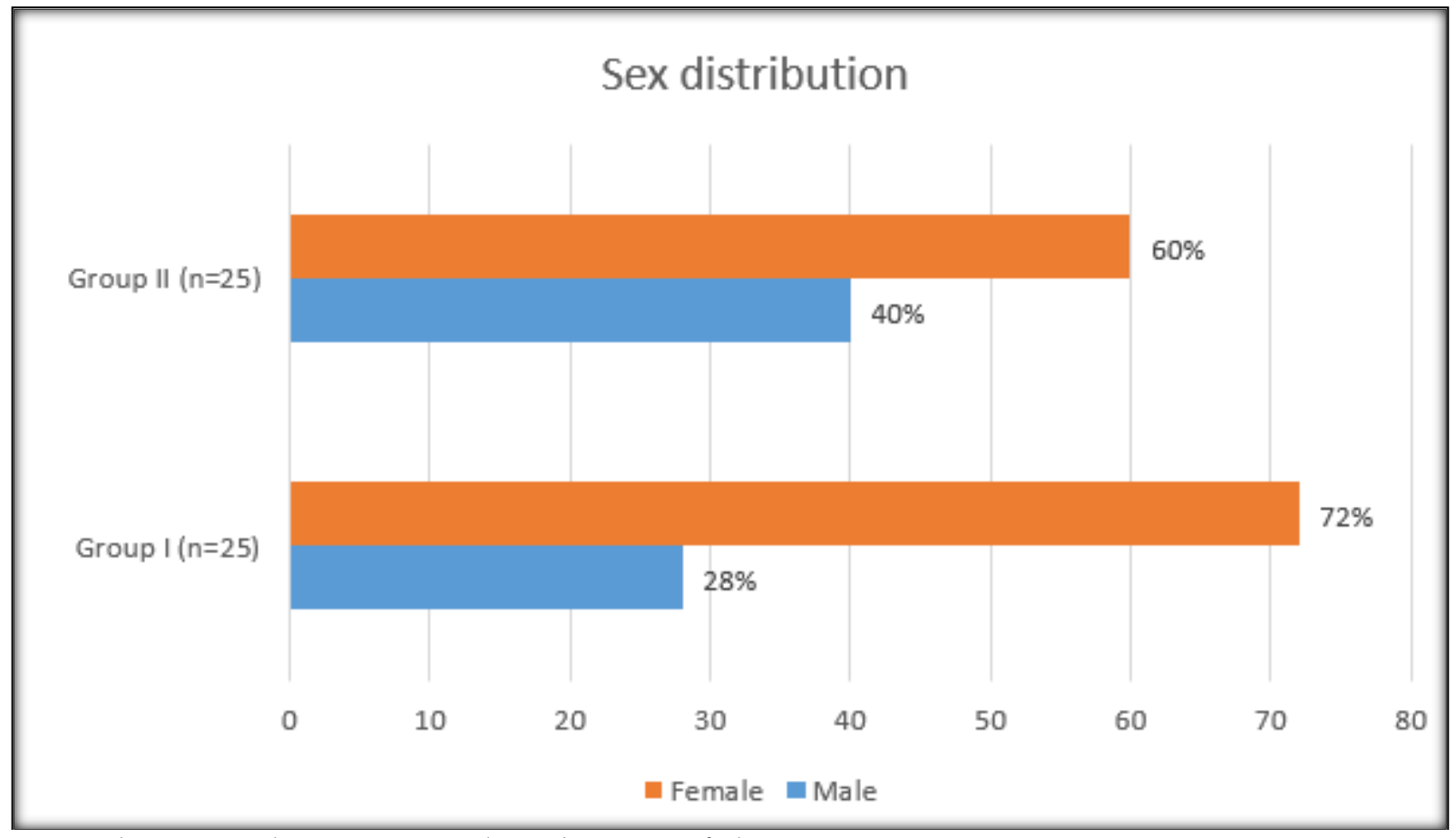

Figure 1: Bar diagram showing sex distribution of the patients

Table 2: Comparison of per-operative variables $(n=50)$.

\begin{tabular}{|l|l|l|l|}
\hline Age (years) & Group I (n=25) (mean \pm SD) & Group II (n=25) (mean $\pm S D)$ & P value \\
\hline $\begin{array}{l}\text { Cardiopulmonary } \\
\text { Bypass Time }\end{array}$ & $55.76 \pm 10.85$ & $131 \pm 31.35$ & P $<0.001^{S}$ \\
\hline Aortic cross clamp time & $28.48 \pm 8.31$ & $83.48 \pm 30.99$ & $\mathrm{P}<0.001^{\mathrm{S}}$ \\
\hline
\end{tabular}


Annals of International Medical and Dental Research

E-ISSN: 2395-2822 | P-ISSN: 2395-2814

Vol-8, Issue-2 | March-April 2022

DOI: $10.53339 /$ aimdr.2022.8.2.27

Page no- 209-218 | Section- Research Article (Cardiac Surgery)

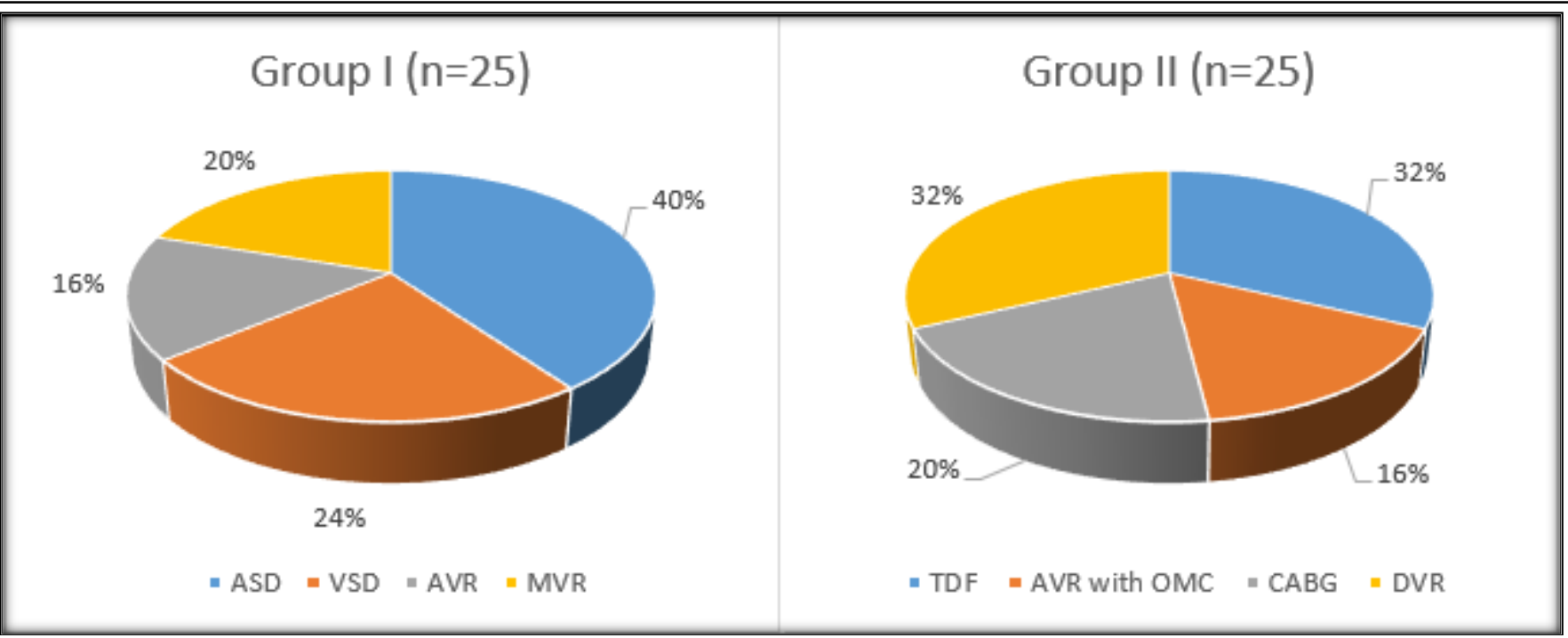

Figure 2: Pie chart showing percentage of different types of operation of the study population

Table 3: Variables of Group I and II at a glance

\begin{tabular}{|c|c|c|c|c|c|c|c|c|}
\hline Day & Group & $\begin{array}{l}\text { Total } \\
\text { count of } \\
\text { WBC }\end{array}$ & $\begin{array}{l}\text { Neutrophil } \\
\text { count }\end{array}$ & CRP & C3 & C4 & APTT & INR \\
\hline \multirow[t]{2}{*}{$\begin{array}{l}\text { Pre-operative } \\
\text { day }\end{array}$} & $\begin{array}{l}\text { Group } \\
\text { I }\end{array}$ & $7.71 \pm 0.94$ & $58.48 \pm 7.76$ & $0.94 \pm 0.60$ & $\begin{array}{l}1.32 \pm \\
0.20\end{array}$ & $0.27 \pm 0.11$ & $30.75 \pm 1.34$ & $1.14 \pm 0.12$ \\
\hline & $\begin{array}{l}\text { Group } \\
\text { II }\end{array}$ & $7.65 \pm 1.01$ & $59.76 \pm 3.59$ & $1.14 \pm 0.61$ & $\begin{array}{l}1.26 \\
\pm 0.19 \\
\end{array}$ & $0.19 \pm 0.10$ & $30.39 \pm 2.86$ & $1.31 \pm 0.27$ \\
\hline \multirow[t]{2}{*}{$\begin{array}{l}1^{\text {st }} \\
\text { Postoperative }\end{array}$} & $\begin{array}{l}\text { Group } \\
\text { I }\end{array}$ & $15.28 \pm 3.87$ & $81.56 \pm 6.00$ & $99.12 \pm 44.33$ & $\begin{array}{l}0.94 \pm \\
0.17 \\
\end{array}$ & $0.21 \pm 0.05$ & $40.41 \pm 6.39$ & $1.40 \pm 0.38$ \\
\hline & $\begin{array}{l}\text { Group } \\
\text { II }\end{array}$ & $15.92 \pm 3.54$ & $82.60 \pm 2.86$ & $109.30 \pm 40.67$ & $\begin{array}{l}0.92 \pm \\
0.18\end{array}$ & $0.17 \pm 0.06$ & $38.78 \pm 9.63$ & $1.18 \pm 1.00$ \\
\hline \multirow[t]{2}{*}{$\begin{array}{l}5^{\text {th }} \\
\text { Postoperative }\end{array}$} & $\begin{array}{l}\text { Group } \\
\text { I }\end{array}$ & $10.24 \pm 1.61$ & $64.08 \pm 7.98$ & $71.35 \pm 0.23$ & $\begin{array}{l}1.35 \pm \\
0.23\end{array}$ & $0.27 \pm 0.05$ & $31.34 \pm 3.75$ & $1.23 \pm 0.16$ \\
\hline & $\begin{array}{l}\text { Group } \\
\text { II }\end{array}$ & $11.42 \pm 2.56$ & $71.72 \pm 6.78$ & $75.73 \pm 67.04$ & $\begin{array}{l}1.35 \pm \\
0.23\end{array}$ & $0.26 \pm 0.09$ & $35.96 \pm 6.39$ & $1.97 \pm 1.77$ \\
\hline \multirow[t]{2}{*}{$\mathrm{P}$ value } & $\begin{array}{l}\text { Group } \\
\text { I }\end{array}$ & $\mathrm{P}<0.001^{\mathrm{S}}$ & $\mathrm{P}<0.001^{\mathrm{S}}$ & $\mathrm{P}<0.001^{\mathrm{S}}$ & $\mathrm{P}<0.001^{\mathrm{s}}$ & $\mathrm{P}<0.02^{\mathrm{S}}$ & $\mathrm{P}<0.001^{\mathrm{S}}$ & $\mathrm{P}<0.01^{\mathrm{S}}$ \\
\hline & $\begin{array}{l}\text { Group } \\
\text { II }\end{array}$ & $\mathrm{P}<0.001^{\mathrm{s}}$ & $\mathrm{P}<0.001^{\mathrm{S}}$ & $\mathrm{P}<0.001^{\mathrm{S}}$ & $\mathrm{P}<0.001^{\mathrm{S}}$ & $\mathrm{P}<0.01^{\mathrm{S}}$ & $\mathrm{P}<0.001^{\mathrm{S}}$ & $\mathrm{P}=0.0145^{\mathrm{NS}}$ \\
\hline
\end{tabular}

One way ANOVA done, $\mathrm{P} \leq 0.05$ is significant, $\mathrm{CRP}=\mathrm{C}$-reactive protein, $\mathrm{C} 3=\mathrm{Complement} \mathrm{C} 3, \mathrm{C} 4=$ Complement C4, APTT= Activated Partial Thromboplastin Time, INR= International Normalized Ratio. 
Annals of International Medical and Dental Research

E-ISSN: 2395-2822 | P-ISSN: 2395-2814

Vol-8, Issue-2 | March-April 2022

DOI: 10.53339/aimdr.2022.8.2.27

Page no- 209-218 | Section- Research Article (Cardiac Surgery)

Table 4: Comparison of postoperative events and complications between two groups.

\begin{tabular}{|l|l|l|l|}
\hline & Group I (n=25) & Group II (n=25) & P value \\
\hline Postoperative ventilation time (Hours) & (n) & $9.16 \pm 2.339$ & ${\mathrm{P}<0.001^{\mathrm{S}}}^{*}$ \\
\hline Postoperative ICU stay\# (Days) & $5.04 \pm 0.20$ & $5.76 \pm 1.45$ & $\mathrm{P}<0.02^{\mathrm{S}}$ \\
\hline Postoperative AF* & $5(20 \%)$ & $12(48 \%)$ & $\mathrm{P}<0.05^{\mathrm{S}}$ \\
\hline Wound infection* & $2(8 \%)$ & $4(16 \%)$ & $\mathrm{P}<0.001^{\mathrm{S}}$ \\
\hline
\end{tabular}

* Chi-square (x2) test done, \# Student's t-test done, AF= Atrial fibrillation, $\mathrm{N}=$ no of patients, NS= Not significant, $S=$ Significant Yate's correction done in Chi-square (x2) test of wound infection and the ' $\mathrm{P}^{\prime}$ value is $<0.001$.

Table 5: Distribution of wound infection among persistently raised CRP populations $(n=7)$

\begin{tabular}{|l|l|l|}
\hline & $\mathbf{n = 7}$ & $\%$ \\
\hline Group I & 1 & 14.29 \\
\hline Group II & 6 & 85.71 \\
\hline Total no of persistently high CRP & 7 & 100.0 \\
\hline
\end{tabular}

\section{DISCUSSION}

The mean age of the patients were $27.40 \pm 10.64$ years in Group-I and $32.60 \pm 14.85$ years in Group II [Table 1], although the mean age of Group-II was higher than that of Group- I. The difference was not statistically significant $(\mathrm{P}=$ 0.162). Comparison could not be done due to scarcity of the literature. Out of 50 patients, females were predominant in both Group I $(72 \%)$ and Group II (60\%). Only $7(28 \%)$ in Group and 10(40\%) in Group II were male. The percentage difference between two groups was not statistically significant $(\mathrm{P}=0.370)$. Bruins and colleagues and Black and colleagues found that the acute phase response was biochemically marked by the enhanced production of the prototypical acute phase protein CRP and by the levels of total C3 and C4 level.113,14] We had also studied the same variables. Our study showed raised CRP in $1^{\text {st }}$ POD but C3 and C4 level declined from their baseline which was dissimilar with the previous study done by Bruins and colleagues.113] Complement C3 and C4 declined from their baseline in our study was probably due to complement consumption. Bruins and colleagues showed that Total complement C3 and $\mathrm{C} 4$ raised after $\mathrm{CPB}$, we also tried to study the Total Complement C3 and C4 but our reagent can only measure $\mathrm{C} 3 \mathrm{c}$ component of complement $\mathrm{C} 3$ and $\mathrm{C} 4 \mathrm{a}$ component of Complement C4.13] This was the cause of dissimilarity of the study done by Bruins and colleagues. [13] In the $5^{\text {th }}$ postoperative day both the $\mathrm{C} 3$ and $\mathrm{C} 4$ again raised to their near normal level. But it never rose beyond the normal range which is contradictory to study done by Bruins and colleagues.[13] Neutrophil count significantly increases on the $1^{\text {st }}$ postoperative (81.56 \pm 6.00 in group-I and $82.60 \pm 2.86$ in groupII) and 5th postoperative day $(64.08 \pm 7.98$ in group-I and $71.72 \pm 6.78$ in group-II) than preoperative value $(58.48 \pm 7.76$ in group-I and $59.76 \pm 3.59$ in group-II). This study was consistent with the study done by Mojcik and colleagues.[8] In each groups [Table 3] total count of WBC was significantly increased on 
Annals of International Medical and Dental Research

E-ISSN: 2395-2822 | P-ISSN: 2395-2814

Vol-8, Issue-2 | March-April 2022

DOI: 10.53339/aimdr.2022.8.2.27

Page no- 209-218 | Section- Research Article (Cardiac Surgery)

1st POD $(\mathrm{P}<0.001)$ and on $5^{\text {th }} \mathrm{POD}$ it decreased significantly $(\mathrm{P}<0.001)$. But the difference between two groups in preoperative, $1^{\text {st }}$ postoperative day and $5^{\text {th }}$ postoperative day were not significant $(\mathrm{P}=$ $0.842, \mathrm{P}=0.545$ and $\mathrm{P}=0.057$ respectively). We could not compare it with other literature due to scarcity of literature. CRP mean value increased after cardiopulmonary bypass, from preoperative value $0.94 \pm 0.60$ to $99.12 \pm 44.33$ on $1^{\text {st }}$ postoperative day in group-I and $1.14 \pm 0.61$ to $109.30 \pm 40.67$ on 1st postoperative day in group-II. And decreased from $1^{\text {st }}$ postoperative day value to $59.86 \pm 36.15$ on $5^{\text {th }}$ postoperative day in group-I and $75.73 \pm 67.04$ on 5th postoperative day in group-II. This result was consistent with the study done by Rothenburger and colleagues.[5] The preoperative mean \pm SD of INR was $1.14 \pm 0.12$ in group I and $1.31 \pm 0.27$ in group II. The difference was significant. On 1st postoperative day there was no significant difference between both groups $(\mathrm{P}=0.145)$, although INR value increased significantly $(\mathrm{P}<0.01)$ in group-I. On $5^{\text {th }}$ postoperative day group- I showed decrease of INR than 1st postoperative day but group II it did not decrease rather increased. The difference was statistically significant between both groups $(\mathrm{P}=0.045)$. This difference was due to preoperative sequalae may be, although the Serum SGPT was not raised preoperatively in the studied population. The rise of INR value after cardiopulmonary bypass was consistent with the study done by Nuttall and colleagues.[15] Kumar and colleagues showed that INR value upto 2 is not associated with excessive bleeding which had similarity with our study.[?]
The mean duration of cardiopulmonary bypass (CPB) time (55.76 \pm 10.85 in group I, $131 \pm 31.35$ in group II; $\mathrm{P}<0.001$ ) and Aortic cross clamp time $(28.48 \pm 8.31$ in group I, $83.48 \pm 30.99$ in group II; $\mathrm{P}<0.001$ ) was higher in group- II than group- I. The difference between the groups was statistically significant. Analysis of outcome variables showed that mean postoperative ventilation time was $6.24 \pm 1.20$ in group I and 9.16 \pm 2.33 in group II [Table 4]. There was significant difference in the ventilation time between two groups $(\mathrm{P}<0.001)$. Five $(20 \%)$ of the patients in group I developed Atrial fibrillation (AF) in the postoperative period, whereas twelve $(48 \%)$ of the patients in group II developed atrial fibrillation in postoperative period [Table 3]. The difference between both groups was statistically significant $(\mathrm{P}<0.05)$. Mean length of ICU stay was $5.04 \pm 0.20$ days in group I and $5.76 \pm 1.45$ in group II [Table 4]. The difference was significant $(\mathrm{P}<0.02)$. This result is consistent with Cappabianca and colleagues.[16] This study showed that there is a definite relationship of wound infection with the prolonged cardiopulmonary bypass time $(\mathrm{P}<0.001)$ and also persistently rising CRP increases the chance of wound infection which was consistent with the study done by Rothenburger and colleagues, Wesselink and colleagues, Kumle and colleagues, Cole and colleagues. $[5,11,12,17]$

None of the patients developed severe systemic inflammatory response syndrome or acute renal failure or severe arrhythmia endangering the life. This result is consistent with Cosgrave and colleagues. [18] 
Annals of International Medical and Dental Research

E-ISSN: 2395-2822 | P-ISSN: 2395-2814

Vol-8, Issue-2 | March-April 2022

DOI: 10.53339/aimdr.2022.8.2.27

Page no- 209-218 | Section- Research Article (Cardiac Surgery)

\section{Limitation of the study}

The present study was conducted in a very short period due to time constraints and funding limitations. The small sample size was also a limitation of the present study.

\section{CONCLUSIONS}

From this study we may conclude that prolonged cardiopulmonary bypass time is associated with increased acute phase response and morbidity of Bangladeshi patients.

\section{Recommendation}

C-reactive protein, Total count of WBC, Neutrophil count, APTT and INR can predict

\section{REFERENCES}

1. Kapoor MC, Ramachandran TR. Inflammatory response to cardiac surgery and strategies to overcome it. Ann Card Anaesth. 2004;7(2):113-28.

2. Kozik DJ, Tweddell JS. Characterizing the inflammatory response to cardiopulmonary bypass in children. Ann Thorac Surg. 2006;81(6):S2347-54.

3. Chen JC, Rollins SA, Shernan SK, Boyce S, Allen K, Wallace A, et al; Pexelizumab Study Investigators. Pharmacologic C5-complement suppression reduces blood loss during on-pump cardiac surgery. J Card Surg. 2005;20(1):35-41.

4. Levy JH, Tanaka KA. Inflammatory response to cardiopulmonary bypass. Ann Thorac Surg. 2003;75(2):S715-20.

5. Rothenburger M, Markewitz A, Lenz T, Kaulbach HG, Marohl K, Kuhlmann WD, et al. Detection of acute phase response and infection. The role of procalcitonin and C-reactive protein. Clin Chem Lab Med. 1999;37(3):275-9.

6. Hall RI, Smith MS, Rocker G. The systemic inflammatory response to cardiopulmonary bypass: pathophysiological, therapeutic, and pharmacological considerations. Anesth Analg. 1997;85(4):766-82. the septic state of the patient. So it should be checked up to 7 th postoperative day.

\section{Acknowledgements}

The wide range of disciplines involved in Acute Phase Response and its Effect on Short Term Outcome of Bangladeshi patients after On-Pump Cardiac Surgery research. We need much assistance from different referees in the evaluation of papers submitted for publication. I am very grateful to my teachers, my guide and many colleagues for their active help, suggestions and their prompt response to requests for their opinion and advice.

7. Hennein HA, Ebba H, Rodriguez JL, Merrick SH, Keith FM, Bronstein MH, et al. Relationship of the proinflammatory cytokines to myocardial ischemia and dysfunction after uncomplicated coronary revascularization. J Thorac Cardiovasc Surg. 1994;108(4):626-35.

8. Mojcik CF, Levy JH. Aprotinin and the systemic inflammatory response after cardiopulmonary bypass. Ann Thorac Surg. 2001;71(2):745-54.

9. Kumar P, Chikkatur R, Kandhachar P, Parida R, Ahuja V, Jadhav E, et al. Preoperative international normalized ratio (INR) and bleeding during openheart procedure. Ind J Thorac Cardiovasc Surg 2004; 20: 132-134.

10. Schneider CP, Angele MK, Hartl WH. Activated partial thromboplastin time waveform analysis as specific sepsis marker in cardiopulmonary bypass surgery. Crit Care. 2010;14(1):104.

11. Wesselink RM, de Boer A, Morshuis WJ, Leusink JA. Cardio-pulmonary-bypass time has important independent influence on mortality and morbidity. Eur J Cardiothorac Surg. 1997;11(6):1141-5.

12. Kumle B, Boldt J, Suttner SW, Piper SN, Lehmann A, Blome M. Influence of prolonged cardiopulmonary bypass times on splanchnic perfusion and markers 
Annals of International Medical and Dental Research

E-ISSN: 2395-2822 | P-ISSN: 2395-2814

Vol-8, Issue-2 | March-April 2022

DOI: $10.53339 /$ aimdr.2022.8.2.27

Page no- 209-218 | Section- Research Article (Cardiac Surgery)

of splanchnic organ function. Ann Thorac Surg. 2003;75(5):1558-64.

13. Bruins $\mathrm{P}$, te Velthuis $\mathrm{H}$, Yazdanbakhsh AP, Jansen PG, van Hardevelt FW, de Beaumont EM, Wildevuur CR, Eijsman L, Trouwborst A, et al. Activation of the complement system during and after cardiopulmonary bypass surgery: postsurgery activation involves C-reactive protein and is associated with postoperative arrhythmia. Circulation. 1997;96(10):3542-8.

14. Black S, Kushner I, Samols D. C-reactive Protein. J Biol Chem. 2004;279(47):48487-90.

15. Nuttall GA, Oliver WC, Beynen FM, Santrach PJ, Strickland RA, Murray MJ. Determination of normal versus abnormal activated partial thromboplastin time and prothrombin time after cardiopulmonary bypass. J Cardiothorac Vasc Anesth. 1995;9(4):35561.
16. Cappabianca G, Paparella D, Visicchio G, Capone G, Lionetti G, Numis F, et al. Preoperative C-reactive protein predicts mid-term outcome after cardiac surgery. Ann Thorac Surg. 2006;82(6):2170-8.

17. Cole DS, Watts A, Scott-Coombes D, Avades T. Clinical utility of peri-operative C-reactive protein testing in general surgery. Ann R Coll Surg Engl. 2008;90(4):317-21.

18. Cosgrave J, Foley JB, Kelly R, McGovern E, Bennett $\mathrm{K}$, Young V, et al. Perioperative serum inflammatory response and the development of atrial fibrillation after coronary artery bypass surgery. Heart. 2005;91(11):1475-6.

Source of Support: Nil, Conflict of Interest: None declared 